OPEN ACCESS

Citation: Raz Kletter (2021) Meeting a Learned Society: The Archaeology of ASOR as Reflected in its Annual Meeting, Boston 2017. Asia Anteriore Antica. Journal of Ancient Near Eastern Cultures 3: 173-193. doi: 10.36253/ asiana-1116

Copyright: (c) 2021 Raz Kletter. This is an open access, peer-reviewed article published by Firenze University Press (http://www.fupress.com/asiana) and distributed under the terms of the Creative Commons Attribution License, which permits unrestricted use, distribution, and reproduction in any medium, provided the original author and source are credited.

Data Availability Statement: All relevant data are within the paper and its Supporting Information files.

Competing Interests: The Author(s) declare(s) no conflict of interest.

\section{Meeting a Learned Society: The Archaeology of ASOR as Reflected in its Annual Meeting, Boston 2017}

\author{
Raz KLetTeR \\ Helsinki University \\ kletterr@gmail.com
}

\begin{abstract}
This article is a study of the ASOR society, based on a database compiled from the 2017 annual meeting at Boston, one of the largest meetings in its history. Such a study has not been performed before. We study the research of ASOR as represented in the meeting by the roles of the scholar-members (poster presenters, lecture presenters, and session chairs), their research subjects (geographic areas, periods, and topics), and their affiliations (gender and institutions). The analysis leads to several questions - and conclusions - about Archaeology in the Ancient Near East (ANE). Despite important progress by ASOR (e.g., in addressing gender), ANE archaeology is still a privilege of the 'west'. Rarely a 'local' scholar spices up the discussions. Modern politics and ideologies determine what areas are studied and what topics of research are 'in'. Political neutrality is proclaimed, but not achieved, in the spaces of the meeting. The aim of the article is to foster discussion about these systematic issues, which do not have easy solutions. By presenting quantified data, they can no longer be dismissed as unsubstantiated, personal impressions.
\end{abstract}

Keywords. ASOR, History of Archaeology, Ethics, Power Relations, Ancient Near East, Oriental, Israel/Palestine.

\section{INTRODUCTION}

The large and important American Society of Overseas Research (at time of writing, still the American Schools of Oriental Research) (ASOR) is unearthing the past of the Ancient Near East (ANE) since 1900, and is itself a worthy subject for research (see King 1983; Seger 2001; Clark and Matthews 2003; Shirley and Seger 2020). In this article we study the current research of ASOR, by using the abstract book of its annual meeting at Boston (Abstract Book 2017) as a database. To the best of our knowledge, no such study has been performed in the field of ANE Archaeology (in other fields see, for example, Simon-Madea 2016). Boston 2017 was one the largest of ASOR's meetings, with over 600 lectures. Hence, it was an 
obvious choice for this study. The data shows diverse aspects of the current research of ASOR, as performed by the scholar-members who have actively participated in the meeting. They performed as poster-presenters, presenters of papers (lecturers) and session-chairs, and we can study their institutional affiliations, gender, and research interests (areas, periods, topics of research, etc.).

This article raises issues that pertain to the Archaeology of the Ancient Near East in the twenty-first century, and its ideological and political backgrounds. Our conclusions can and should be debated. An open discussion will do ASOR the best service and reflect best its noble mission of 'fostering original research, encouraging scholarship, and disseminating research results while adhering to the highest ethical standards of scholarship and public discourse' (Abstract Book 2017:4).

The Boston Abstract Book (Fig. 1), with more than 600 abstracts, gives a good picture of current ASOR research. ${ }^{1}$ There are, naturally, limitations. The book does not represent all those attending the meeting. Some scholar-members attend the meeting, but do not give presentations; others do not attend (membership of ASOR, at about 1800 members, is not limited to scholars). A study of one meeting cannot offer a longue durée, but hopefully, it can be achieved by future studies of more meetings.

The data in the Abstract Book is also partial. An abstract is not always a precise summary of a delivered presentation. To know, one has to attend the presentation; but this is impossible with 600 presentations, of which many are simultaneous. A few last-minute changes or cancellations might not appear in the Abstract Book (but do not affect the general conclusions). The institutional affiliations marked for the presenters (except the so-called 'independent scholars', which are few) do not match exactly nationality, ethnicity, or residence. We can connect an affiliation to a country (or countries), where the research is being administered (even if the fieldwork is done in the ANE).

ASOR maintains overseas centers in the ANE (Luke and Kersel 2013; Kersel and Luke 2018). Yet almost all the scholars that participated in the Boston meeting under such an affiliation, for example, from the Albright Institute in Jerusalem, work there temporarily; they are not 'locals'. Hence, they are considered here according to the host institutions (mostly in the USA). The American University of Beirut operates only in Lebanon and is not an organic part of ASOR; therefore, scholars affiliated to it are labeled under 'Lebanon'. Needless to say, a few cases of doubt exist in any database of this kind; but their number is small.

We discuss the data in three sections, according to the different roles of the scholar-members participating in the meeting: posters, presentations, and sessions. ${ }^{2}$

\section{POSTERS}

Thirty-seven 'posters on parade' were presented in Boston. The geographic regions dealt with by the posters were Jordan (10 posters), Israel (8), Cyprus (4), Turkey (4), Arabia and the Persian Gulf (3), Iraq and Iraqi Kurdis$\tan (2)$, and Egypt (1). Two more posters concerned the Southern Levant, a term that usually denotes Israel/Palestine, Jordan, and northern Sinai. The remaining three posters were more general in scope: one on the history of the Dead Sea Scrolls, the second on tholos architecture, and the third on loom-weights.

The geographical regions (above) reflect modern states. The ancient cultures, which have existed in the same areas, usually cut the modern borders or are subsumed within them. The four Turkey-labelled posters give an

\footnotetext{
${ }^{1}$ For disclosure, the author participated in the 2017 and in various other annual meetings of ASOR. Some of the terminology of the Abstract Book is followed here, for example "presentations" (and not lectures/papers) and "chairs" (not chairpersons). Common abbreviations are used for periods: EB for Early Bronze, MB for Middle Bronze, and LB for Late Bronze. The periods are equated between regions (e.g., EB with Early Dynastic Mesopotamia and Old Kingdom Egypt). Such approximations enable us to avoid breaking up the discussion between different regions. Areas follow modern entities. Mesopotamia, however, includes Iraq and parts of Syria and Turkey. We kept 'Mesopotamia', because many presentations (e.g., on cuneiform sources) do not fit modern borders.

${ }^{2}$ We do not discuss here keynote speakers and managerial roles (board and committee members). Since the contribution of this article is not in the realm of statistics, we use simple percentages and avoid statistical jargon.
} 
example: though they are related to sites in modern Turkey, three concern the Hatai region, which can be seen, culturally, as North Syrian in some periods. The fourth poster, on Kültepe in central Turkey, is partially 'Mesopotamian' in that it treats cuneiform documents. There were no posters in the 2017 meeting about the Hittite Empire, Urartu, or Phrygia, which are all cultures of Asia Minor, presently Turkey. None of the four Turkey-labelled posters was made by a scholar affiliated with a Turkish institution.

Twenty-six posters were focused on more-or-less specific periods of time. The most popular period was the Iron Age (11 posters: five on Israel, two on Arabia, two on south-eastern Turkey; and one each on Jordan and Iraqi Kurdistan). Second in place was the Hellenistic/Roman periods (five posters: two on Cyprus, and one each on Egypt, Israel, and Jordan), followed by Prehistory and EB (four posters, on Jordan and the Southern Levant) and the MB (three posters on Iraq, Jordan, and Turkey). Two posters (on Israel and Turkey) were dedicated to the LB period, one (on Cyprus) to the MB-LB, and one to pre-Islamic Arabia. Ten other posters where not focused on a specific period.

Among the ten posters on Jordan, four encompassed a wide range of time, and the rest were divided, with one poster for each of the following periods: Prehistory, EB, MB, Iron Age, and Roman. In contrast, five of the eight posters on Israel were dedicated to the Iron Age. The focus on the Iron Age period in the archaeology in Israel is not a new phenomenon. It relates to modern national feelings, since this period is viewed as 'our' period, of the Kingdoms of Israel and Judah, or the First Temple period (in past studies also called 'the Israelite period'; on archaeology and nationalism in Israel see Roth and Meskell 2002; Baram and Rowan 2004; Kletter 2006; Kohl et al. 2007; Thompson 2009; Oestigaard 2013; Sherrard 2015).

Seven posters were dedicated to pottery; six presented a site or a group of sites, and two addressed each of the following subjects: settlement patterns, textiles/weaving, architecture, and art. Other subjects (agriculture, heritage, history of archaeology, etc.) were represented by single posters.

Seventy-eight scholars participated in making the posters. Four posters involved large teams of scholars: nine (all from the American Center of Oriental Research at Amman - in this case tagged 'Jordan', based on the names); seven (five scholars from the USA, two from Dubai); six (all USA); and four (three from the USA and one from Israel). Teams of three scholars cooperated in five posters (two posters by American teams, one Israeli, one German, and one 'mixed' team from the USA, Canada, and Germany). Pairs of scholars were responsible for eight posters (five USA pairs, one Czech pair, one USA-UK pair, and one Germany-Italy pair). It seems that cross-country cooperation in posters was quite limited, mostly to excavation projects shared by scholars from several countries. Twenty posters were presented by single scholars, as follows: USA (11), Canada (5), Australia (1), Finland (1), Spain (1), and the UK (1).

The posters were quite equally divided between female (41) and male (36) scholars (we did not manage to verify gender in one case). The dominancy of the 'West' in the archaeology of ASOR can be seen by the fact that the majority (59) of the poster makers have 'western' affiliations (USA 41, Canada 6, Germany 5, Czech Republic 2, UK 2, and one each from Italy, Finland, and Spain). Scholars from institutions in the Middle East were a small minority: nine from Jordan/ACOR (all in one poster; but the institution itself was 'western', and likely not all the nine participated in person in the meeting), seven from Israel, and two from Dubai. ${ }^{3}$

Religious influence on the archaeology of the ANE should be discussed (ASOR itself was founded by ministers and for many years dedicated to Biblical Archaeology). However, the present database is too limited for studying this aspect. The religious affiliation of some institutions (mainly from the USA) is noted in their titles. For example, institutions of the Seventh Day Adventists (posters by five scholars), Baptists (three), and Mormons (three). However, such affiliations do not necessarily reflect the beliefs of individual scholars. Other institutions may carry religious titles on account of their long history, without having a religious character at present.

Data from the books of the ASOR meetings can be used to chart social networks of scholars, based on their sharing of posters, presentations, sessions, etc. Recent, interesting work on this subject is performed by Edwards

\footnotetext{
${ }^{3}$ We excluded the 36 'Digital Posters' (Abstract Book 2017: 54-55) from the discussion, because these posters focused on one specific aspect - digital archaeology - and were perhaps chosen by different criteria than the regular posters.
} 
(for preliminary results see Edwards 2019). One must be aware that such networks reflect power relations more than scientific qualities. Scientific work happens across the entire network, in each and every nodule. Whether some nodules are described by Social Network Analysis in terms of 'weak' or 'strong', it bears no relation to their scientific merits. Many scholars in the humanities tend to work alone or in small groups. The scientific quality of their work has no direct match to the number of the 'connections' that they share. ASOR rules wisely state that a scholar can give only one presentation and serve as chair of only one session per each annual meeting. Occasionally, exceptions are made for scholars who come from far-away countries and/or do not have sufficient funds to join every year. Unfortunately, in recent years at least some fame-driven scholars have managed to bypass the rules. Usually, it is professors with access to large grants who direct teams of excavations (or other large projects). They hold a position of power over their students. They use it to plaster their names on posters and presentations, which are the product of the students. ${ }^{4}$ The students are in no position to object; they are told that it is an honor and a common procedure to share work in this way with the heads of the project. In fact, it is a means of self-publicity, adorning oneself with borrowed plumes. To give examples, in the 2017 Boston meeting one professor was named on 16 posters, and in the San Diego meeting (Abstract Book 2019) one professor was named in the title of seven presentations, beside a panel discussion and a chair-role..$^{5}$ A professor may appear alone on one lecture, and together with team members on another, in the same meeting, concerning the same site (for example, compare Abstract Book 2017: lectures 2cl and 2j3). It seems that the ideology of "shared by all" binds the team members, but not the professors who direct them.

This deserves condemnation, not admiration. Fame-driven scholars might claim that they should be mentioned in titles (not, as should be the case, in acknowledgements), because they make the studies possible by raising the necessary funds. Following this logic, titles of posters, presentations, and scientific publications should include also the names of the donors, because they too make the studies possible. Also, names of rectors and presidents of universities and of related State officials.

\section{PRESENTATIONS}

We numbered each presentation ('lecture' in other conferences) according to the session initials in the Abstract Book and a running number (so for example, the second presentation in session $3 \mathrm{c}$ is ' $3 \mathrm{c} 2$ '). We excluded cancelled presentations (when made known in advance). In total, we counted 602 presentations, delivered over three days (days 1-3, 16th-18th November 2017; the plenary presentation was marked as Day 0).

It was difficult to decide, for one item, if it was a mere introduction to a session, or a full presentation. The short program (Abstract Book 2017: 35) referred to this item as an introduction, but the abstract (Abstract Book 2017: 133, 6j1) gave it in the format of a full presentation (bold title, full abstract). The author wrote:

I will present the main finds from the five seasons of excavations conducted at the site, and summarize their implications for the history of the site from the first settlement during the Early Bronze Age III period, through the Middle Bronze Age, when the site was fortified with a mud brick wall on a solid stone foundation, and mainly during the Late Bronze Age, when remains were found in almost all the excavated areas. I will focus also on the Iron Age IIA and IIB period, from which remains are also found in most parts of the site... An important part of the presentation [sic] will be the next settlement peak at the site that happened during the Persian period and continued into the early Hellenistic period... (Abstract Book 2017: 133).

All this and more in five minutes? Fifty-five more sessions at Boston included short introductions (Abstract Book 2017: 20-55), and the chairs never thought that their introductions required a long, special abstract. They

\footnotetext{
${ }^{4}$ It seems, but this goes beyond the subject of this article, that some also add their names to publications that are generated by their students, under the pretext that "all the team" shares every publication.

${ }^{5}$ Referring by the session initials and a running number, the presentations were $7 \mathrm{c} 2,7 \mathrm{~h} 5,8 \mathrm{e} 4,9 \mathrm{i} 3,1 \mathrm{gg} 5,12 \mathrm{~g} 5$, and 12g6; the panel discussion 8i; and the chair-role $11 \mathrm{~g}$.
} 
just wrote 'introduction', that's all. This chair invented a new academic genre: a long, detailed abstract for a fiveminute introduction. Giving it the benefit of doubt, we counted 602 presentations. $^{6}$

\subsection{Geographical Areas of Presentations}

The most popular area in terms of presentations was Israel (168 presentations, $28 \%$ of all presentations) (Table 1), followed by Mesopotamia (55, 9.1\%), Jordan (54, 9\%), Turkey (40, 6.6\%), and Egypt (35, 5.8\%). The list was closed by few presentations that related to the outskirts of the ANE (Libya, Tunisia, Central Asia, and the Caucasus).

If one considers the size of each area, the disparity in the geography of the presentations is obvious. For Turkey, each presentation 'covered' an area of about $19,575 \mathrm{~km}^{2}$, while for Jordan 1655 and for Israel 124.

Cyprus and Lebanon were quite well represented (27 and 17 presentations, respectively), considering their relatively small areas. ${ }^{7}$ The Aegean World (including Greece) was practically missing, except a few presentations on western Turkey. This is because Greece is traditionally considered to be part of Europe, not of the ANE.

Syria was hardly represented, except the north Syrian/Orontes area, which was divided, since five-six presentations about it were tagged 'Syria' (with Cilicia, 12) and nine 'Turkey'.

Israel dominated the meeting with 168 presentations (ca. 28\%). It also tended to dominate sessions on the 'South Levant' and 'South Phoenicia'. One obvious reason for this is the participation of many scholars from Israel, who often receive funds for travel to conferences from their institutions. Also, the stability and friendly relations of Israel with the USA encourage work in Israel and travel to conferences in the USA. There is also the presence of branches of 'foreign' research in Israel, particularly the Albright Institute in Jerusalem. Finally, there is the influence of 'the Land of the Bible' (even if explicit 'biblical' presentations were few at Boston).

\subsection{Periods of Presentations}

Of 602 presentations, 138 were general, that is, they encompassed several periods, or had no clear indication of a specific period (Table 2). Excluding these general presentations, the Bronze Age (ca. 2300 years) was represented by 153 presentations; the Iron Age (600 years) by 91; the Classical - Hellenistic to Byzantine - periods (1000 years) by 106; and the 'Late' (Islamic to Modern) periods (1400 years) by 46 . Most of the presenters, therefore, dealt with the Bronze, Iron, and Classical periods.

Prehistory barely appeared, while the long Neolithic and Chalcolithic periods received modest attention. We see a steady flow of presentations on the EB (32), MB (44) and LB (37) periods (roughly $5.3-7.3 \%$ of all the presentations). Then, a sharp increase with 91 Iron Age presentations (15\%). The Roman Period was the most popular among Classical periods (28 presentations). Presentations on Islamic periods were rare (13, 2.2\%); but interest revived in the modern period (33 presentations, $5.5 \%)$.

\subsection{Topics of Presentations}

The variety of the subjects offered at the 2017 meeting was impressive. Popular topics were, in alphabetic order: Archaeozoology and Archaeobotany: 18 presentations (11 and seven, respectively).

Architecture (palaces, fortifications, gates...): 30

Art history (frescoes, statues, masks, etc.): 20

Burial and death: 32 .

\footnotetext{
${ }^{6}$ We based the analysis on the more detailed abstracts, and noticed the discrepancy $v s$. the short program for this item only at a later stage. ${ }^{7}$ In earlier meetings of ASOR there were only a few presentations on Lebanon (I thank one of the readers of Asiana for this observation). So the relatively large number in 2017 may well be an exception. As mentioned, we have here the picture of one meeting, not a representative picture over time.
} 
Complexity (mainly formation of cities/states): 17.

Data analysis and recording (GIS, CRANE, ARCHEM, OCHRE): 27.

Economic aspects (debt, slavery, trade, weights, hoards, etc.): 35.

Excavation and survey reports: 63 (mostly on recent/current projects).

Gender: 20 .

Heritage and cultural resources: 17.

Honorary presentations: 12 .

Pottery: 29.

Religion (temples, cults, votive objects, etc.): 29.

Science in Archaeology: 18.

Seals: 12.

Settlement patterns: 13 .

Texts and inscriptions: 47.

Water (baths, réservoirs, tsunami deposits, etc.): 17.

Other presentations (101) included the following topics: biblical (6), figurines (8), glass (6), History of archaeology (4), identity (8), maritime archaeology (9), senses (6), and overseas centers (6). Thirty-seven additional presentations were defined as 'general', covering an array of different subject, such as transitions between periods and stratigraphy.

\subsection{The Presenters}

The total number of presenters was 846 . It signifies roles rather than people, since some presenters were listed more than once (in shared presentations); quite many presentations were shared by two (78 presentations), three (29), and even more scholars (26).

Fourteen presentations were listed with four scholars each; six with five scholars; two with six scholars (6c1; 1j1); two with seven scholars (3c2, 11a4), one with nine scholars (1a3), and one with 12 (9a1). Did so many persons make together one presentation? It is unlikely. Many of those listed did not even attend the annual meeting. We have therefore decided that in the case of presentations with four or more names, we register the first two and the last, and exclude the rest as 'additional' scholars. We did not apply the same measure to posters, since the number of posters (and posters with many co-authors) was small. ASOR requires that the name of the person delivering the presentation is underlined in the program. When marked thus, we included this person, regardless of the order in the list. Based on these criteria, we defined 56 'additional' scholars, 16 female and 40 male. ${ }^{8}$ We believe that excluding them reduces biases.

The remaining 790 presenter-roles were quite evenly divided between men (190) and women (174). (Table 3) As expected, the USA led the list with 364 presenter-roles (46.1\%). This is only natural for a conference of a USA society that is held in the USA. The second place was occupied by Israel, with 168 presenter-roles (21.3\%); but of them, men (102) outnumber women (66).

Only three other countries had more than 20 representatives: the UK (39, 4.9\%), Canada (35, 4.4\%), and Germany (24, 3\%). Next in order were several European countries - Italy (19 presenters), France (15), Austria (13), and the Netherlands (11).

Together, the 16 represented European countries had 163 presenter-roles (20.7\%), equally divided between women (81) and men (82). ${ }^{9}$ In contrast (excluding Israel), ten countries located in or on the outskirts of the Near

\footnotetext{
${ }^{8}$ Seven of the 'additional' female scholars were affiliated with the USA, two were independent scholars, and one each was affiliated with Austria, Australia, Canada, Denmark, France, Italy, and Poland. Of the forty 'additional' male scholars, nine were affiliated with Israel, eight with the USA, seven with Georgia (all in one presentation, 9a1), four with Dubai, two with Australia, two with France, two with Germany, and one each with Belgium, Canada, Spain, Tunisia, and Turkey (add one independent scholar).

9 The countries were: Austria, Belgium, Czech Republic, Denmark, Finland, France, Germany, Greece, Italy, the Netherlands, Norway, Poland, Spain, Sweden, Switzerland, and the UK.
} 
East (Cyprus, Dubai, Greece, Iran, Iraq, Jordan, Lebanon, Libya, Tunisia, and Turkey) had only 31 presenter-roles (3.9\%; 18 women and 13 men).

The vast majority of the presenter-roles were affiliated with the 'West' (USA, Canada, and Europe: 562 roles, $71.2 \%)$, and about a fifth with Israel (168, 21.3\%). The economic giants of the Far East were barely represented, and the same was true about Middle Eastern countries (excluding Israel).

\subsection{Discussion of Presentations and Presenters}

So far, we have looked at separate aspects of presentations and presenters. Here we offer observations about relations between these fields.

ASOR has made significant progress towards gender equality, but there are still borders to cross. All the ten presenters in the two gender sessions (10i, 11e) were women, affiliated (except one from Spain) with USA institutions. Presenters in the 'dress and body' sessions (9b, 10b) were almost all women too. Is gender a feminine subject, does it 'happen' only in the (north-) western Hemisphere? Does such an unbalanced representation reflect rooted conservativism in archaeology, or in the ASOR? Or, it is a random feature of one meeting? Comparisons to more meetings are necessary before one can reach conclusions.

With European countries, the USA, and Canada, there was equality in the roles of presenters between women and men; however, considerably more male (102) than female (66) presenter-roles were from Israel. This varied between institutions (Table 4).

Against sessions with mostly women with USA affiliations presenting on gender, there were sessions with predominantly men from Israeli institutions presenting on Iron Age Israel. In the 'Yerushalayim, Al Quds, Jerusalem I' session (1b), five men from Israeli institutions discussed the First and Second Temple periods. Only one USAbased presenter was female, giving the sole 'Al Quds' presentation in this session. The 'Archaeology of Israel I' (2c) did include one woman (and four men); but the 'Archaeology of Israel II' (3c) was composed of eight men (if we include the four 'additional' scholars of $3 \mathrm{c} 2$, the ratio "improves" to 12:1). Adding two more sessions, on Persian Period Judah (4i) and 'Rethinking Israel' (8c, an Honorary session), the overall ratio in five sessions (1b, 2c, 3c, $4 \mathrm{i}, 8 \mathrm{c})$ is 26 men to four women; and the chairs were all men too. Similarly, in the two 'Archaeology and Biblical Studies' sessions ( $3 \mathrm{~b}, 4 \mathrm{~b}$ ) the ratio of men to women was 14:2. Compare this with the nearly equal ratio in the three sessions on 'Iraqi Kurdistan' (2a, 3a, 4a): 12 men and nine women. The scholars lecturing on Iraqi Kurdistan were mostly from the USA. One may suggest that they bring gender equality with them to an area that is 'traditional', despite the challenging working conditions there. Yet, the 'western' and Israeli scholars who lecture on Iron Age Israel, Persian period Israel, Archaeology in Israel, and Biblical Archaeology work in the opposite direction: they carve a chauvinistic niche at the heart of 'western' science.

We do not imply that every conference session must be gender balanced. The composition of a single session can be random or unintentional. ${ }^{10}$ However, the analysis (above) seems to reflect a trend.

The 168 presenter-roles affiliated with Israeli institutions involved 126 presentations. A hundred of them (79\%) were on the area of Israel. Of the rest, eight presentations were on the Levant and Southern Levant, and six on Phoenicia (some of these presentations were also focused on Israel). Remaining were a few presentations on Egypt (3), Syria (1), Cyprus and Israel (1), Levant and Cyprus (1), and four general presentations. This implies that scholars affiliated to Israeli institutions hardly discuss other areas than Israel. It is partly due to the fact that Israelis cannot work in neighboring, mostly Arab countries.

Concerning periods, 25 of these 126 presentations were general. The remaining 101 presentations were divided as follows: Prehistory and the Bronze Age (28 presentations); LB-IR (3); Iron (29); Persian and Persian-Hellenistic (7); Classic (29); Islamic/Medieval (3); and Modern periods (2). So the archaeology of scholars from Israeli institu-

\footnotetext{
${ }^{10}$ Such as that of a session on economy chaired by the author ('Meeting the Expenses', ASOR 2019). Of all those invited, those who actually joined the session happened to be all men.
} 
tions is focused on 'our' periods - the Iron Age and the Classic periods; that is, the First and Second Temple and the Mishna and Talmud. Compare the data about tenured positions in Israel: in the academic year 2010/11 there were 66 fully-tenured faculty positions in archaeology in Israeli institutions. Of them, 40 (c. 61\%) were in the fields of the Bronze, Iron and Classical periods, and only three in Islamic and medieval archaeology (Mazar 2011: 12). No data was given as to how many of the positions were held by women (on the underrepresentation of women in academic conferences in Israel see Eden 2016).

To compare with Israel, we grouped eight countries into an arbitrarily 'European entity' (Austria, Belgium, Canada, France, Germany, Italy, the Netherlands, and the UK). Together, these countries had 186 presenter-roles in 132 presentations, equally divided between women (94) and men (92). Enjoying better access, the presenters of this imaginary 'European entity' studied many areas: the Aegean (3 presenters), Far Asia (2), Arabia (7), Cyprus (5), Egypt (13), Iran (3), Iraqi Kurdistan (9), Israel (14), Jordan (1), Lebanon (6), Levant and Southern Levant (3), Libya (1), Mesopotamia (19), Syria (10), and Turkey (8); 17 other presentations were general). The presenters of the 'European entity' dealt with Prehistory and the Bronze Ages (63 presentations), more than with the Iron and Classic periods. ${ }^{11}$ To be fair, they represent only the 'Near Eastern' segment of the archaeology of their countries. Were we to analyze archaeology as a whole, say, in Austria or France, we would probably discover that the majority of the archaeologists working there focus on the archaeology of Austria and France (and perhaps on periods that are considered especially important to the Austrians and the French).

Is there a difference in presentations between the days of the conference? We compared the 223 presentations on Day 1 with the 198 presentations on Day 3. Both days saw similar numbers of presentations on Egypt (11 on both days), Iran and central Asia (seven on Day 1, nine on Day 3); Lebanon (4:3), Mesopotamia (16:19), and Syria (6:4). Sometimes, allocation of one-two sessions on a specific topic means that this topic is limited to a single day.

However, Day 1 appeared to be the day of Israel, Iraqi Kurdistan and, to a lesser degree, Jordan (Table 5). It was also an Iron Age day, with 47 Iron Age presentations (21\% of the day's total). Day 3 was the day of Arabia, Libya, Turkey, and the Biblical Exodus. A title with the explicit 'biblical' word is rare in recent ASOR meetings. Was the allocation of this session to Day 3 random? Or, did it reflect a relegation to the same status as the abovementioned Arab countries? We cannot tell. Yet, Iron Age presentations became a rarity in Day 3 - only 12 (6.1\%). Day 2 stood in the middle with 32 Iron Age presentations (17.1\% of the 181 presentations).

Clearly, the Iron Age had a preference in the Boston meeting, being given the 'center-stage' of the first day. Perhaps it was also related to the movement, by Day 3, of presenters engaged in biblical archaeology to the parallel conference of the Society of Biblical Literature (SBL).

\section{SESSIONS AND WORKSHOPS}

In this part we consider the larger units in the conference - the sessions and the role of chairs. In total, there were 120 sessions in the meeting. We refer to them by the codes in the abstract book $(2 \mathrm{c}, 9 \mathrm{~d}$, etc.).

\subsection{Geographical Areas of Sessions}

Many sessions were general (the entire ANE, the Levant, etc.). Geographical areas covered by one-two sessions included Iran (1), Libya (1), Lebanon (2), the Northern Levant (1), and Southern Phoenicia (2). ${ }^{12}$ They all represented Islamic countries, except Southern Phoenicia, divided between Israel and Lebanon. Areas discussed by three-four sessions each were Arabia (3); Egypt (3, including two Hyksos sessions, covering also the Southern

\footnotetext{
${ }^{11}$ Presumably, there are specific conferences for Classical archaeology, where European scholars can present, so joining the ASOR meeting is not a 'must' for them. It is also, for them, more expensive than joining a conference in Europe.

12 'Southern Phoenicia' is a term used by scholars to denote northern Israel (e,g,, sites like Achzib/Zib and Tell Keisan, which were Phoenician) and southern Lebanon. See, for example, Gilboa 2005; Eshel et al. 2018; Sader 2019: 9, 17).
} 
Levant); Mesopotamia (3); Iraqi Kurdistan (3); Cyprus (4), and the Southern Levant (4). There were also three 'biblical' sessions ( $3 \mathrm{~b}, 4 \mathrm{~b}$, and $11 \mathrm{~g}$ ), but no sessions on Syria, perhaps due to the crisis there.

Turkey seemed to be well represented with seven sessions. However, one of these was shared for Turkey, Armenia and the Caucasus (9A), and three concerned the Orontes region, which may be defined culturally as North Syrian $(7 \mathrm{~g}, 8 \mathrm{~g}, 11 \mathrm{~h})$. This left only three 'Turkish' sessions (two on Anatolia, one on Sardis).

Jordan was represented by eight sessions and two more were mostly about Jordan (11f and 10e). Israel was represented by the highest number of sessions (14). Consider that there were also more presentations on Israel in sessions on the Southern Levant, Southern Phoenicia, and biblical archaeology.

\subsection{Periods of Sessions}

Many sessions were general (77), or encompassed a wide range of time, such as Chalcolithic to Iron Age (1), or Early Bronze to Iron (2).

Prehistory was not represented in titles of sessions, and the Bronze Age in general only in two (9g; 4g; several 'general' sessions included Bronze Age presentations, e.g., $3 \mathrm{k}$ and 10j). There were two more 'early' sessions: Chalcolithic-Bronze (1) and EB-MB (1). Bronze and Iron as one continuum was quite popular ( 7 sessions). Two sessions were focused on the MB and two on the MB-LB. While no session was 'purely' LB, four were mixed LB-Iron sessions. The Iron Age was covered by six sessions. One session discussed the Iron-Persian periods, and one the Persian period. Nine sessions were dedicated to the Classical (Hellenistic to Byzantine) periods.

Islamic periods were hardly represented. Two sessions were defined as Hellenistic to Islamic and Classic to Islamic, and one 'Islamic Society' session (10h) included presentations from Byzantine to modern. Six sessions treated the recent/modern world (the history of archaeology, career options, and gender).

\subsection{Themes of Sessions}

Many sessions were general. We divided 82 sessions with more specific topics into the following groups:

1. Sites (11 sessions, seven of which concerned sites in Israel).

2. Inscriptions and seals (six sessions: inscriptions four, seals and sealing two).

3. Computerization, digital data, cyber research, etc. (six).

4. Cultural heritage and history of archaeology (five).

5. Sciences (five: archaeobotany/archaeozoology, bioarchaeology, isotopic investigations, organic residues, and technology in archaeology).

6. Gender (four: gender two; dress and the body two).

7. Economy (four).

8. Biblical archaeology/Exodus (three).

9. Sessions in honor of scholars (three).

The remaining 36 sessions were varied. ${ }^{13}$ The wide range of subjects is notable, and ASOR should be proud of being able to offer such a variety.

\footnotetext{
${ }^{13}$ Altered states/complexity (2 sessions); ambiguity (3); art history (2); baths-bathing (1); borders of cities/kingdoms (1); career options (2); Classic periods (1); connectivities (2); death and dying (1); digital humanities (1); engaging global challenges (1); feasting/foodways (1); glass (1); houses/households (2); Hyksos (2); identities (2); interconnections (1); Islamic society (1); Yehud (1); maritime archaeology (1); religion (1); senses and sensibilities (2); settlement landscape (1); theory/anthropology (1); and violence (2).
} 


\subsection{Chairs of Sessions}

Sessions were normally organized by one or two chairs. Only one session was registered under four (all from the USA), and three under three scholars each (one USA team; two 'mixed' USA-UK teams). Forty-six sessions were chaired by pairs of scholars. Of them, thirty were pairs from institutions in the US and one from Israel. The other pairs formed 'international' teams: Austria-Lebanon (2); Italy-Canada (2); Israel-Canada (1); USA-France (7); USAItaly (1); USA-Libya (1); and USA-UK/Qatar (1). Seventy sessions had one chair, affiliated to institutions from the USA (50), Israel (10), Canada (3), Austria (2), Lebanon (2), Finland (1), France (1), and Germany (1). To stress again, these are work affiliations, not a direct match for nationalities and ethnicities. An example, perhaps atypical, is the author - born in Israel, resident of Estonia, and chairing a session with affiliation in Finland.

The 120 sessions were organized by 175 chair-roles (some persons chaired two sessions, while others shared the same session): 92 males and 83 females. The 131 USA chair-roles were divided equally between female (68) and male (63). Similarly, the 19 chair-roles with European affiliations included 11 men and eight women. However, the 13 Israel-affiliated chair-roles included only two women.

Perhaps for US tenured scholars, being a chair in an ASOR meeting is a duty more than a prestigious role. Still, it is a role that reflects hierarchy, one step above presenters, with its special badge - a green ribbon added to the name tag. It seems that this role at Boston was equally divided between USA and European men and women, while from Israel only a few women reached the position of chairs.

\subsection{Sessions by Days}

Comparing the days of the conference, we find that some sessions (on careers, Jordan, and Mesopotamia) were evenly distributed (Table 6). Yet, ten sessions on Israel were placed on Day 1 and four on Day 2. More presentations on Israel in the two 'Southern Phoenicia' sessions were also placed on Day 1. In contrast, there was not even one session on Israel in Day 3, but this day saw sessions on Arabia, Turkey, Egypt, Libya, Islamic Society, the Northern Levant, and Gender. ${ }^{14}$

If one wishes to focus on the Archaeology of Israel, the concentration of so many sessions on one day is a hindrance. Religion plays a factor here, since Day 3 is Saturday (affecting observant Jews and Seventh Day Adventists). However, the large majority of presenters from Israeli institutions at ASOR are not religious. Likely, since chairs cannot know in advance who will submit proposals for papers, they ask not to put their sessions on a Saturday. Naturally, this should be respected. However, the result is lack of equality. Many presenters, who are not observant, enjoy lecturing on Day 1, year after year; on Friday evening or Saturday they move to the green fields of the SBL conference. $^{15}$

\subsection{ASOR-Sessions versus Member-Sessions}

Are there significant differences between standing ASOR sessions and those organized by members? With standing sessions, the subjects are fixed and members are asked to be chairs. In member sessions the chairs choose the subjects.

There were 55 ASOR standing sessions at Boston (henceforward, A-sessions) ${ }^{16}$ and 65 member sessions (M-sessions). The 76 A-sessions chair-roles (38 women, 38 men) were almost exclusively from USA institutions (except

\footnotetext{
${ }^{14}$ In the seven last ASOR meetings (2013-2019), the gender sessions sponsored by ASOR were placed once on Day 1 (2014), twice on Day 2 (2015, 2018), and three times on Day 3 (2013, 2016, 2019).

15 This Exodus is hardly observant, if moving with luggage involves vehicles. The issue is not the (excellent) organization of the Boston meeting, but constraints placed on it by preferences/conflicts of participants. Perhaps a slight change of date will benefit ASOR, to prevent having Saturday as Day 3 and also avoid a conflict with the conference of the American Anthropological Association.

${ }^{16}$ Including session 9c, missing from the list (Abstract Book, 2017:202-204).
} 
three Canadian, two Italian, two French, and one Lebanese affiliation). The $65 \mathrm{M}$-sessions were chaired by 99 chair-roles ( 51 women, 48 men). Of them, 65 were related to USA institutions (women 34, men 27) and 34 to institutions abroad (women 11, men 23, mainly due to the 'contribution' of Israeli institutions).

Otherwise, the sessions were quite similar. There were 257 presentations in A-sessions and 344 in M-sessions. Both types of sessions had similar numbers of presentations on most of the areas (Table 7). A-sessions included fewer 'general' presentations than M-sessions, probably because they focus on specific areas, which do not fit well 'general' presentations.

Concerning periods, there were more MB presentations in M-sessions (34) than in A-sessions (10); the same with MB-LB (15:5, respectively) and Classic periods (28 to 12). A-sessions included 87 general presentations (in terms of periods), as against 47 in M-sessions. A-sessions encompassed 157 female and 203 male presenter-roles; whereas in M-sessions the relation was 221:210. ${ }^{17}$ So it seems that while members reflect gender equality in their roles as chairs of member-sessions, the A-session chairs accept more men than women as presenters in A-sessions.

\section{MISSING ‘OTHERS’ AND ETHICS}

One 'other' that is missing at ASOR is Palestine. Israelis and Palestinians share the same land. A presentation on Jericho can be labeled under Israel, Palestine, or even Jordan (which ruled this area in 1948-67). We tagged presentations as 'Israel' when they appeared in sessions titled 'Archaeology of Israel' or were offered by scholars from Israeli institutions.

Members from the Albright Institute in Jerusalem suggested that ASOR maintains neutrality in Middle East politics (Abstract Book 2017: 183-184). This is also the official ASOR website position. Yet in the meeting halls one can hardly find this neutrality. Israel is dominant ( 97 presentations on the prestigious first day) while Palestine is an absentee. In the history page (Abstract Book 2017: 7) 'Palestine' appears only as a term from the past, before 1948. There is no session on the Archaeology of Palestine, and not even one of the books advertised in the abstract book mentions Palestine. Add the stress on 'our' periods and the scarcity of sessions on Islamic periods.

Presentations like 9i3 reflect the atmosphere. The title and abstract seem neutral: the 'Jordan Valley five miles north of Jericho', survey and ethnographic work in a modern 'Bedouin' village. The real focus is, however, the 'adaptive strategies of the settlers' of an Iron Age site (Abstract Book 2017: 159). The 'Bedouins' are Palestinian Muslims, the site is located in the West Bank, and the presenters excavated there even before the 2017 meeting (so it was not just a 'survey'). ${ }^{18}$ It was not a salvage excavation. One presenter is affiliated to Averett, a Baptist University, ${ }^{19}$ and the second with Ariel University, located in the West Bank and identified with the modern Israeli settlers. ${ }^{20}$ ASOR's professional code of conduct endorses the Hague Convention and its first protocol, but not the second protocol of 1999 (for which see O'Keefe, 2006: 261-3; Gerstenblith 2014: 86-87, 95). ${ }^{21}$ The second protocol prohibits 'any archaeological excavation, save where this is strictly required to safeguard, record or preserve

\footnotetext{
${ }^{17}$ Since the available data from the meeting has nothing on third genders, the discussion is limited to women and men.

18 http://digs.bib-arch.org/digs/khirbet-el-mastarah.asp (accessed December 2017); https://www.christianpost.com/news/archaeological-discovery-evidence-hebrew-exodus-from-egypt-found-near-jordan-river-227564/ (accessed October 2018);

19 http://www.insidehighered.com/news/2011/12/01/controversy-shorter-over-faith-statements ; and http://blog.bibleplaces. com/2016/11/new-excavation-khirbet-el-mastarah-in.html; https://www.facebook.com/jordanvalleyexcationproject/ (accessed December 2018).

20 The project's aims, as presented to students, do not mention any "Bedouins": "Are you fascinated by the book of Joshua and its stories about the miraculous crossing of the Jordan River, how the walls of Jericho tumbled down, and how Joshua defeated Hazor, "the head of all those kingdoms" (Josh 11: 10)? If so, then you should definitely volunteer to work on the pioneering new excavation at Khirbet el-Mastarah, located just west of the Jordan River in what may have been the area of the earliest Israelite settlement. This intriguing site [...] is dated to the time of the first settlement of the Tribes of Israel, as described in the book of Joshua" (http://averett.abroadoffice.net/internal-program-description-REL-315-Archeology-and-the-Bible-BIO400-Field-Experience-in-the-BiologicalSciences--169209-0.html (Accessed June 2018). Compare Hawkins and Ben-Shlomo 2018; Bohatrom and Schuster 2018.

${ }^{21}$ http://www.bu.edu/asor/about/policies/conduct.html (accessed December 2017), especially paragraphs III.B.3-5.
} 
cultural property' in occupied territories. We do not raise this issue as a legal case, but as an ethic one: by giving such a presentation a respected public stage, ASOR promotes it. This is not 'neutrality'.

Perhaps ASOR does not care much for ethics, despite the claim about 'the highest ethical standards' in its mission statement (Abstract Book 2017:4). ${ }^{22}$ The mission statement is limited mainly to excavating and to preventing trade in antiquities. Being an ethical archaeologist is not just about safekeeping the remains of the past. It is mainly about our relationships today (Williams 2013:288; Zorzin 2014: 116; Kletter 2019).

In the 2012 meeting of ASOR in Chicago, Jane Cahill and Robert Mullins chaired a session about ethics and excavations in East Jerusalem (for this subject see Sulimany 2013; Greenberg 2014; Feige 2015; Hason 2017; Greenberg 2018; Sulimani and Kletter 2017; Kletter 2019). ${ }^{23}$ The session was disturbed by people who did not agree with the opinions of Rafi Greenberg and (presumably) others. The result was that ASOR decided not to hold such sessions in the future. By this act, ASOR gave a prize to those who disrespect academic etiquette. It is not avoiding politics, but supporting the politics of one side and preventing open discussion.

Tellingly, there were no sessions on ethics at Boston (or in the meetings of 2018-19). Only one of 602 abstracts (by Rannfrid Thelle, 8f1) and one of 37 posters (by Rachel Risk and Deirdre Fulton) mentioned the word 'ethics' (Abstract Book 2017: 147, 192).

\section{CONCLUSIONS}

The ASOR meeting in Boston was a large and successful meeting. The organization was excellent and the scope of the presentations wide: the use of derelict buildings in Oman (12a5)? Curved snakes on objects from Iran (7f5)? Smiling terracotta camels from Sardis (9h5)? All these and much more was on offer. There was also a healthy interest in scientific methods and the digital world.

However, the old ASOR (cf. Sherrard 2011) was present too. Research was focused on limited slices of the ANE, stressing Israel and Jordan. Difficulties of access are not the fault of scholars, but we should be aware how the borders of our science are shaped by modern politics and ideologies. There were sessions on 'Iraqi Kurdistan', since this area became more accessible recently (Ur 2017). Will the ASOR dare call similar sites, only slightly more northward, 'Turkish-Kurdistan'? Certainly not. Palestine was an absentee and there were no sessions on Greece, because it is 'Europe'. The Boston meeting could accommodate sessions on Tunisia and the Caucasus, but Greece was kept outside the 'Orient'. ${ }^{24}$

The (temporary) lack of sessions on Syria in the Boston meeting raises the worry that too much is focused on excavations (Kletter and De Groot 2001; Bonnie 2011; Cherry 2011). When the shower of new digs is cut, the presentations might dry up.

ASOR made significant progress concerning gender, but the timing of the gender sessions at Boston left something to be desired. With audiences fresh and excited, Day 1 held manels on the Iron Age Archaeology of Israel. The gender sessions were placed on Day 3, when many have already left for the SBL conference. The lack of presentations by men in the gender sessions is also a worry, though not the fault of ASOR or of the chairs of these sessions.

Archaeology of the ANE has always been, and is, a privilege of the 'West'. We replicate the old Colonial model of archaeology (Pollock and Bernbeck 2005; Moro-Abadía 2006; Hamilakis 2012; La Salle and Hutchings 2018). Rarely a 'local' scholar spiced up the discussion in Boston. The 18 presentations on Iraqi Kurdistan (sessions 2a, 3a,

\footnotetext{
${ }^{22}$ Hopefully this will change: in the coming 2020 Annual Meeting two member-organized sessions are devoted to ethics. We also should not ignore the work done in 2013 (Dodd 2013).

${ }^{23}$ The session (A80) was titled "Current Issues in Biblical Archaeology", with the theme "Legal, Ethical, Political, and Social Issues Posed by Excavations at the City of David in East Jerusalem. That it was decided not to accept such sessions was told to me unofficially by a board member.

${ }^{24}$ A ray of light in the Denver 2018 meeting was a session discussing to finally drop the 'Oriental' from the name of ASOR, organized by Danielle Fatkin and Kathleen Bennallack. The word was dropped out since and the entire or 'wider' Mediterranean is now in focus.
} 
4a), by 21 presenter-roles, were affiliated to American, European, and Japanese institutions; only one scholar had a 'local' affiliation (2a5). In the two 'Archaeology of Jordan' sessions (7d, 8d) only one of 15 presenter-roles was from a Jordanian institution. Excluding Israel, among 161 chair-roles only four were affiliated to Near-Eastern countries.

Going to the ASOR annual meeting is an expensive business. This explains much of the scarcity of 'local' presenters from less-rich countries, where institutions do not regularly cover expenses for academic travels. For a German or a Swiss, participation in the ASOR meeting means (roughly) two weeks' salary. ${ }^{25}$ For someone from Turkey or Jordan, it means an equivalent of 3-4 months of work, and from Tunisia or Syria, 6-8 months. Add the strict visa requirements of the USA. The scientific gap is an economic and political gap.

Our analysis also warns against the trend of putting "all the names" on the titles of lectures (and publications), and on seeing scholars in terms of 'strong' or 'weak' nodules in a social network. The use of SNA is beneficial, but networks must also be seen in terms of power relations. Science happens across the network; the social status of scholars do not match the scientific merits of their work. ASOR should adhere to its rules, which limit participation to one lecture and one chair role per meeting, and condemn, not praise, those who manage to by-pass them.

In the Boston meeting Israel held an exceptional position. In between the developed and the developing worlds, native and colonial at the same time. More than a fifth of all the presenter-roles in Boston were affiliated to Israeli institutions $(168,21.3 \%)$. The East-Coast location (Boston) is maybe one factor. More important are the political stability and friendly relations, which draw 'western' scholars to Israel and Israelis to the ASOR meetings. Israeli archaeology is a success story, being led by Israeli scholars. In developed countries this is the norm, but not so in all the Near Eastern countries. Another important factor is the allure of the Bible, with the related stress on the Iron and Classical periods (First and Second Temple, the time of Jesus, etc.). Biblical Archaeology thrives in ASOR, although the word 'biblical' is no longer common in titles of lectures and sessions. The picture of Israeli archaeology as represented by most of the Israel-affiliated scholars at Boston was nationalistic and secluded.

It is worthwhile to compare the Boston meetings with a similar, large-scale meeting in Europe. We can treat here, as an example, only one aspect of such a meeting. The ICAANE 12 meeting in Bologna (postponed due to Corona to 2021 and held digitally) included a total of 593 lectures (Callieri et al. 2021). Of them, 53 lectures (c. 9\%) were focused on the area of Israel (one more lecture 'mixed' Israel and Jordan, Callieri et al. 2021: 317). The 53 lectures treated the following periods: Prehistory 6 (1 Paleolithic, 4 Natufian, 1 Chalcolithic); Bronze Age 14 (1 general, 7 EB, 1 EB4-MB, 2 MB, 1 MB-LB, and 2 LB); LB and Iron Age 4; Iron Age 10, Persian 1; Classical Periods 7 (1 Hell-Rom, 1 Rom-Byz, 4 Roman, and 1 Byzantine); and Islamic Periods 6 (a few more lectures were not period-specific). In the 381 pages of the ICAANE 12 abstract book, the word Israel (also Israeli, Israelite, Kingdom of Israel, but excluding private names) appeared 33 times in the abstracts of 20 lectures. ${ }^{26}$ The majority of the lecturers on the area of Israel did not use this term, but 'Southern Levant' (or, rarely, Canaan). This could be a personal choice, an adaptation to the circumstances/audiences of ICAANE, or both. In this meeting we see a different facet of Israeli Archaeology than that seen at Boston. Namely, the early periods were important and Islamic periods had a place, as against the acute stress of 'our' periods in the Boston meeting. ${ }^{27}$

Presentations like 9i3 in Boston raise more issues of politics and ethics. ASOR should maintain political neutrality as far as possible, but this cannot be achieved by mere declarations (cf. Davies 2017). It requires awareness to the political uses/abuses of archaeology and a readiness to engage with them.

Some of our conclusions are not surprising - and could be felt just by entering the conference spaces from

\footnotetext{
${ }^{25}$ Based on average salaries. Academics earn much more, but presumably the gap is maintained between levels of salaries in different countries.

${ }^{26}$ Eight of these references were in a single lecture, Callieri et al. 2021: 225).

27 The 53 lectures did not include 6-7 lectures on areas of the Palestinian Authority, labelled as "Palestine". Palestine was not an absentee in this meeting - the term Palestine/Palestinian was mentioned 28 times in relation to 16 lectures. The ICAANE 12 abstract book (arranged by alphabetical order) and program (arranged by days and themes) did not give the affiliations of scholars (except for opening addresses and keynote speakers). There are a few cases of doubt with sorting the lectures by periods/regions, but they require no further discussion here.
} 
the more multi-cultural streets outside (cf. Peters 2017 about the SBL). The ASOR Annual Meeting seems content inside the white marble halls of the same regularly visited, wealthy American cities. In part it is related to keeping the conferences beside those of the SBL; but the conference also serve as a showcase of affluence. The SBL is trying to reach out to new communities, and its International Conference at least is moving to new places.

Boston was charming (Fig. 2), and reading the entire ASOR 2017 book from A to Z for the sake of science was a unique pleasure. Using the database, the issues discussed here can no longer be treated as unsubstantiated impressions. They are deep, systemic issues, which do not have an easy solution. Addressing them with an open mind will advance ASOR's mission and make it more relevant today.

\section{ACKNOWLEDGMENTS}

I wish to thank Morag Kersel and Rick Bonnie for reading the manuscript, and the readers and editors of AsiAnA for their contributions to improving the paper.

\section{BIBLIOGRAPHY}

Abstract Book 2017, ASOR Annual Meeting Program and Abstract Book. Boston, November 15-18, 2017, Winona Lake, Eisenbrauns.

Abstract Book 2019, ASOR Annual Meeting Program and Abstract Book. San Diego, November 20-23, 2019, Winona Lake, Eisenbrauns.

Baram U., Rowan Y. 2004, Archaeology after Nationalism, in Y. Rowan, U. Baram (eds), Marketing Heritage. Archaeology and the Consumption of the Past, Walnut Creek, Altamira Press: 3-26.

Bohatrom P., Schuster R. 2018, Is this where the Israelites camped on their Way to Canaan 3,200 Years ago? Haaretz Megazine, January 1, 2018, https://www.haaretz.com (accessed June 2018).

Bonnie R. 2011, Haven't we dug enough now? Excavation in the Light of Intergenerational Equity, Archaeological Dialogues 18/1: 48-58.

Callieri P. et al. 2021, 12 th ICAANE. 12th International Congress on the Archaeology of the Ancient Near East. Bologna, April 6-9, 2021. Abstract Book, Bologna, Bologna University, http://www.12icaane.unibo.it/.

Cherry J.F. 2011, Still Not Digging, Much, Archaeological Dialogues 18/1: 10-17.

Clark D.G., Matthews V.H. 2003, 100 Years of American Archaeology in the Middle East (Proceedings of the American Schools of Oriental Research Centennial Celebration), Boston, ASOR.

Davies P. 2017, The PEF and the Perils of Neutrality, Palestine Exploration Quarterly 149/1: 1-2.

Dodd L.S. 2013, ASOR and Archaeological Ethics, ASOR Blog, April 5, 2013, https://asorblog.org/p_4333.html.

Eden D. 2016, Women's Participation in Academic Conferences in Israel Journal of Higher Education Policy and Management 38/4: 406-421.

Edwards, S. 2019, Who are the "Best-Connected" Members of the ASOR Community?, in ANE Today VII no. 5, May 20, 2019, www.asor.org/anetoday/.

Emberling G. 2010, Pioneers to the Past. American Archaeologists in the Middle East 1919-1920, Chicago, The Oriental Institute.

Eshel T. et al. 2018, Four Iron Age Silver Hoards from Southern Phoenicia: From Bundles to Hacksilber, Bulletin of the American Schools of Oriental Research 379: 197-228.

Feige M. 2015, "Where it all began". Archaeology, Nationalism, and Fundamentalism in Silwan, in F. Markowitz et al. (eds), Toward an Anthropology of Nation Building and Unbuilding in Israel, Nebraska, University of Nebraska Press: 243-258.

Gerstenblith P. 2014, Beyond the 1954 Hague Convention, in R. Albro, B. Ivrey (eds), Cultural Awareness in the Military: Developments and Implications for Future Humanitarian Cooperation, London, Palgrave Macmillan: 83-99. 
Gilboa A. 2005, Sea Peoples and Phoenicians along the Southern Phoenician Coast - A Reconciliation: An Interpretation of Šikila (SKL) Material Culture, Bulletin of the American Schools of Oriental Research 337: 47-78.

Greenberg R. 2014, A Privitized Heritage: How the Israel Antiquities Authority relinquished Jerusalem's Past, Jerusalem, Emek Shaveh Reports, www.alt-arch.org.

Greenberg R. 2018, One Hundred Years of Archaeology and Controversy in Jerusalem, in S.A. Mourad et al. (ed.), Routledge Handbook on Jerusalem, London, Routledge: 363-376.

Hason N. 2017, Urshalim. Israelis and Palestinians in Jerusalem 1967-2016, Rishon Lezion, Miskal (Hebrew).

Hamilakis Y. 2012, Are We Postcolonial Yet? Tales from the Battlefield, Archaeologies: Journal of the World Archaeological Congress 8: 67-76.

Hawkins R.K., Ben-Shlomo D. 2018, Khirbet el-Mastarah: An Early Israelite Settlement?, Biblical Archaeology Review 44/4, https://www.baslibrary.org/biblical-archaeology-review/44/4/5 (accessed June 18, 2018).

Kersel M.M., Luke C. 2018, Introduction: The Power of Place at the U.S. Overseas Research Centers, Heritage, Diplomacy, and Archaeology, Journal of Eastern Mediterranean Archaeology \& Heritage Studies, 6/3: 167-171.

King P.J. 1983, American Archaeology in the Mideast: A History of the American Schools of Oriental Research, Philadelphia, ASOR.

Kohl P.L., Kozelsky M., Ben-Yehuda, N. (eds) 2007, Selective Remembrances. Archaeology in the Construction, Commemoration, and Consecration of national Pasts, Chicago, University of Chicago Press.

Kletter R. 2019, The Ethics of East Jerusalem, in Archaeology, Heritage and Ethics in the Western Wall Plaza, Jerusalem. Darkness at the End of the Tunnel, London, Routledge: 166-180.

Kletter R., De-Groot A. 2001, Excavating to Excess. The Last Decade of Archaeology in Israel and its Implications, Journal of Mediterranean Archaeology 14: 76-86.

La Salle M., Hutchings R.M. 2018, “What Could Be More Reasonable?” Collaboration in Colonial Contexts, in Oxford Handbooks Online. Archaeology, Cultural Heritage and Public Archaeology, Doi: 10.1093/oxford$\mathrm{hb} / 9780190676315.013 .22$.

Luke C., Kersel M.M. 2013, US Cultural Diplomacy and Archaeology: Soft Power, Hard Heritage, Abingdon, Routledge. Machinist P. 1996, William Foxwell Albright: The Man and his Work, in J.S. Cooper, G.M. Schwartz (eds), The Study of the Ancient Near East in the Twenty-First Century, Eisenbrauns, Winona Lake: 385-403.

Mazar A. 2011, Israeli Archaeology: Achievements and the Current State of Research, Bulletin of the Anglo-Israel Archaeological Society 29: 9-21.

Moro-Abadía O. 2006, The History of Archaeology as a 'Colonial Discourse', Bulletin of the History of Archaeology 16/2: 4-17.

Oestigaard T. 2013, Israel and Palestine: A Critique of How to Create and Anchor a Nation-State Archaeologically, in E. Pfoh, K. Whitelam (eds), The Politics of Israel's Past. The Bible, Archaeology and Nation-Building, Sheffield, Phoenix Press: 120-136.

O'Keefe R. 2006, The Protection of Cultural Property in Armed Conflict, Cambridge, Cambridge University Press.

Peters K.R. 2017, When Women Speak: A Reflection on Our Field, https://ubc.academia.edu/KRPeters (accessed December 2017).

Pollock S., Bernbeck R. 2005, Archaeologies of the Middle East. Critical Perspectives, Oxford, Blackwell.

Roth A.M., Meskell L. (eds) 2002, Archaeology under Fire. Nationalism, Politics and Heritage in the Eastern Mediterranean and Middle East, London, Taylor and Francis.

Sader H. 2019, The History and Archaeology of Phoenicia, Atlanta, SBL Press.

Seger J., et al. 2001, An ASOR Mosaic: A Centennial History of the American Schools of Oriental Research, Boston, ASOR.

Sherrard B. 2011, American Biblical Archaeologists and Zionism: The Politics of Historical Ethnography, PhD Thesis, Florida State University.

Sherrard B. 2015, American Biblical Archaeologists and Zionism: How Differing Worldviews on the Interaction of Cultures Affected Scholarly Constructions of the Ancient Past, Journal of the American Academy of Religion 84/1: 234-259. 
Shirley M., Seger J.D. 2020, A History of ASOR: The 1970's to the Present, ASOR News 7, 2020. http://www.asor. org/news/2020/07/

Silberman N.A. 2002, Whose Game is it anyway? The political and social Transformations of American Biblical Archaeology, in A.M. Roth, L. Meskell (eds), Archaeology under Fire. Nationalism, Politics and Heritage in the Eastern Mediterranean and Middle East, London, Taylor and Francis: 175-188.

Simon-Madea A. 2016, A Corpus-based Study of the AAAL Conference Handbook, Journal of English for Academic Purposes 23: 71-82.

Sulimani G. 2013, Israeli Archaeology in the Old City of Jerusalem, in E. Pfoh, K. Whitelam (eds), The Politics of Israel's Past. The Bible, Archaeology and Nation-Building, Sheffield, Phoenix Press: 120-136.

Sulimani G., Kletter R. 2017, Bone Considerations. Archaeology, Heritage, and Ethics at Mamilla, Jerusalem, International Journal of Cultural Property 24: 321-350.

Thompson T. 2009, Biblical Archaeology and the Politics of Nation-Building, Holy Land Studies 8/2: 133-142.

Ur J. 2017, The Archaeological Renaissance in the Kurdistan Region of Iraq, Near Eastern Archaeology 80/3: 176187.

Williams J.F. 2013, Archaeological Ethics in Armed Conflicts, PhD Thesis, University of Leicester.

Zorzin N. 2014, Archaeology and Capitalism: Successful Relationship or Economic and Ethical Alienation?, in C. Gnecco, D. Lippert (eds), Ethics and Archaeological Praxis, New York, Springer: 115-140. 
Table 1: Areas - 602 Presentations.

\begin{tabular}{|c|c|c|}
\hline Area & No. & Sub-area and/or comments \\
\hline Aegean & 9 & Including Crete (7b4, 11b4), Greece (5i5), and Turkey and Greece (11b3). \\
\hline Farther Asia and Iran & 27 & $\begin{array}{l}\text { Afghanistan (4f5, 5a1); Armenia (1f5, 9a4, 12f4); Bactria (5a2); Caucasus (9a1, 12d2, 12d3); Mongolia (12d5); } \\
\text { Indus Valley (3k6); Iran-Central Asia (3k2, 9b5); Turkmenistan (7f2); Zagros (2d1); and Iran (12 presentations). }\end{array}$ \\
\hline Arabia & 19 & \\
\hline Cyprus & 27 & Including two on Cyprus and Egypt/Israel (6e1, 5e3). \\
\hline Egypt & 35 & Including two on Nubia (11d1, 11d5), two on Egypt and Sinai (1d4, 4d1), and one on Egypt and Israel (9f5). \\
\hline $\begin{array}{l}\text { General/more than } \\
\text { one area }\end{array}$ & 69 & Including seven on biblical subjects. \\
\hline Iraqi Kurdistan & 18 & Including one that discussed also the Zagros Mts. (3a1). \\
\hline Israel & 168 & Including three on Israel and Jordan/Sinai $(3 \mathrm{~b} 6,3 \mathrm{f} 5,12 \mathrm{e} 4)$. \\
\hline Jordan & 54 & Including one comparing Jordan and Cambodia ( $5 c 5)$. \\
\hline Lebanon & 17 & \\
\hline $\begin{array}{l}\text { Levant, South Levant, } \\
\text { South Phoenicia }\end{array}$ & 31 & $\begin{array}{l}\text { Levant } 7 \text { (including one Levant-Cyprus); South Levant } 16 \text { (including one South Levant-Cyprus, and two focused } \\
\text { on Israel); South Phoenicia } 8 .\end{array}$ \\
\hline Libya, Tunisia & 5 & Libya 5 (10f1-5); Tunisia one (6c1). \\
\hline Mesopotamia & 55 & Including one marked as Iraq ( $7 \mathrm{c} 3)$. \\
\hline Palestine & 7 & \\
\hline Syria & 21 & Of them, five are marked as Orontes, one north Syria, and one Zinçirli. \\
\hline Turkey & 40 & $\begin{array}{l}12 \text { discussed Anatolia, } 6 \text { Sardis, } 5 \text { Antioch, } 3 \text { Cilicia, } 2 \text { Kanish, } 2 \text { Lycia, } 1 \text { Hattusha, } 4 \text { Hatai/Orontes/Euphrates } \\
\text { areas, and } 4 \text { Turkey in general. }\end{array}$ \\
\hline
\end{tabular}

No. $=$ no. of presentations.

Table 2: Periods - 602 Presentations.

\begin{tabular}{|c|c|c|}
\hline Period & $\mathrm{N}$ & Sub-periods and comments \\
\hline $\begin{array}{l}\text { Prehistory and } \\
\text { Chalcolithic }\end{array}$ & 34 & $\begin{array}{l}2 \text { Holocene/Pleistocene (10a1, 10c3); } 4 \text { Prehistory and Prehistory-Bronze; } 8 \text { Neolithic; } 1 \text { Neolithic-Chalcolithic; } \\
4 \text { Neolithic-EB; } 9 \text { Chalcolithic, } 3 \text { Chalcolithic-EB (1a2, 2j6, 11b1), } 1 \text { Chalcolithic-LB (2a2), } 1 \text { Chalcolithic-MB } \\
\text { (9j3), } 1 \text { Chalcolithic-Bronze (1e6). }\end{array}$ \\
\hline Bronze Age general & 17 & 13 general; four EB-MB (4g1, 9e1, 9c3, 9a3) \\
\hline Bronze EB & 32 & \\
\hline Bronze EB4/MB1 & 3 & \\
\hline Bronze MB & 44 & \\
\hline Bronze $\mathrm{MB}$ and $\mathrm{LB}$ & 20 & \\
\hline Bronze LB & 37 & \\
\hline LB-Iron & 10 & \\
\hline Iron Age & 91 & Including one on Iron and Neo Babylonian periods in Israel (1g2). \\
\hline Iron-Persian & 3 & \\
\hline Persian & 21 & Including two Persian-Classic and two Persian-Hellenistic presentations. \\
\hline Classic general & 54 & $\begin{array}{l}\text { Classic general 22; Roman-Byzantine 13; Hellenistic-Roman 9; Nabatean } 4(5 \mathrm{j} 2,8 \mathrm{~d} 3,11 \mathrm{f} 2,11 \mathrm{f3}) \text {; Hellenistic- } \\
\text { Byzantine 2; four other (1a4, 4a1, 10d3, 12a4). }\end{array}$ \\
\hline Classic Hellenistic & 10 & \\
\hline Classic Roman & 28 & Including three Late Roman $(7 \mathrm{j} 4,9 \mathrm{~h} 6,11 \mathrm{~h} 2)$. \\
\hline Classic Byzantine & 14 & \\
\hline $\begin{array}{l}\text { Islamic, Medieval, and } \\
\text { Ottoman }\end{array}$ & 13 & $\begin{array}{l}9 \text { Islamic (four Islamic in general, two Early Islamic, one Ayyubid, one Islamic and Modern, and one Byzantine } \\
\text { and Early Islamic); one Crusader-Mamluk (7i6); two medieval (7a4,3b1); and two Ottoman (12b3-4). }\end{array}$ \\
\hline Modern & 33 & On the history of archaeology, heritage management/protection, gender today, career options, ethnography, etc. \\
\hline General & 138 & $\begin{array}{l}\text { Including } 11 \text { Bronze-Iron; } 5 \text { MB-Iron; } 2 \text { Classic and medieval (5a3, 11h5); } 2 \text { Byzantine-Crusader (2b6; 12h3); } \\
\text { and one each on: Chalcolithic-Byzantine (10c4), Byzantine-modern ( } 4 \mathrm{a} 3) \text {, Iron-Islamic (2b4); Iron Age Europe } \\
\text { (1f5), Iron-modern ( } 9 \mathrm{i} 3) \text {; Classic-Abbasid-Crusader (7j3); and Classic-Medieval (5f4). }\end{array}$ \\
\hline
\end{tabular}

Notes: $\mathrm{N}=$ number of presentations. 
Table 3: Affiliation and Gender - 790 Presenter Roles.

\begin{tabular}{|c|c|c|c|}
\hline Affiliation & Female & Male & All \\
\hline Argentina & 1 & & 1 \\
\hline Armenia & 1 & 2 & 3 \\
\hline Australia & 5 & 4 & 9 \\
\hline Austria & 8 & 5 & 13 \\
\hline Belgium & 5 & 4 & 9 \\
\hline Canada & 18 & 17 & 35 \\
\hline Cyprus & 2 & & 2 \\
\hline Czech Republic & 1 & 4 & 5 \\
\hline Denmark & 1 & 1 & 2 \\
\hline Dubai & & 1 & 1 \\
\hline Finland & 3 & 1 & 4 \\
\hline France & 9 & 6 & 15 \\
\hline Georgia & 1 & & 1 \\
\hline Germany & 13 & 11 & 24 \\
\hline Greece & & 1 & 1 \\
\hline Independent Scholar & 5 & 4 & 9 \\
\hline Iran & 1 & 1 & 2 \\
\hline Iraq & 1 & 2 & 3 \\
\hline Israel & 66 & 102 & 168 \\
\hline Italy & 10 & 9 & 19 \\
\hline Japan & & 4 & 4 \\
\hline Jordan & 4 & 2 & 6 \\
\hline South Korea & 1 & & 1 \\
\hline Lebanon & 4 & 5 & 9 \\
\hline Libya & 1 & & 1 \\
\hline Mexico & 1 & & 1 \\
\hline The Netherlands & 7 & 4 & 11 \\
\hline Norway & 1 & & 1 \\
\hline Poland & 3 & 5 & 8 \\
\hline South Africa & 1 & & 1 \\
\hline Spain & 2 & 3 & 5 \\
\hline Sweden & & 3 & 3 \\
\hline Switzerland & 1 & 3 & 4 \\
\hline Tunisia & 1 & & 1 \\
\hline Turkey & 4 & 1 & 5 \\
\hline United Kingdom & 17 & 22 & 39 \\
\hline United States & 174 & 190 & 364 \\
\hline Total & 373 & 417 & 790 \\
\hline
\end{tabular}

Note: three independent scholars were affiliated by countries, based on personal knowledge. 
Table 4: Affiliations of Presenter Roles - Israeli Institutions.

\begin{tabular}{lcccccccc}
\hline & Haifa Univ. & $\begin{array}{c}\text { Hebrew } \\
\text { University } \\
\text { Jerusalem }\end{array}$ & $\begin{array}{c}\text { Tel Aviv } \\
\text { Univ. }\end{array}$ & $\begin{array}{c}\text { Bar Ilan } \\
\text { Univ. }\end{array}$ & $\begin{array}{c}\text { Ben } \\
\text { Gurion } \\
\text { Univ. }\end{array}$ & $\begin{array}{c}\text { Ariel } \\
\text { Univ. }\end{array}$ & IAA & Others \\
\hline Female & 19 & 19 & 14 & 3 & - & - & 5 & 6 \\
Male & 17 & 17 & 22 & 9 & 3 & 4 & 18 & 12 \\
Total & 36 & 36 & 36 & 12 & 3 & 4 & 23 & 102 \\
\hline
\end{tabular}

Notes: IAA = Israel Antiquities Authority; Univ. = university. Other institutions include the Geological Institute (1f), Weitzman (1f), Kinneret College (1f, 4m), Nature and Parks Authority (2m), Hebrew Union College (1f, 2m), Israel Museum (1f, 1m), Technion (1f), and three independent male scholars.

Table 5: Presentations - Days 1 and 3.

\begin{tabular}{lcclcc}
\hline Area & Day 1 & Day 3 & Area & Day 1 & Day 3 \\
\hline Iraqi Kurdistan & 17 & 1 & Arabia & - & 18 \\
Israel & 97 & 21 & Biblical & - & 6 \\
Jordan & 22 & 10 & General & 15 & 29 \\
Levant/South Levant & 10 & 5 & Libya & - & 5 \\
South Phoenicia & 8 & - & Turkey & 6 & 33 \\
\hline
\end{tabular}

Table 6: Sessions - Days 1 and 3.

\begin{tabular}{|c|c|c|c|}
\hline DAY 1 (43 sessions) & No. & DAY 3 (41 sessions) & No. \\
\hline General sessions & 19 & General sessions & 15 \\
\hline Modern period (career options 1, digital humanities 1) & 2 & $\begin{array}{l}\text { Modern period (cultural diplomacy overseas centers 1; applying } \\
\text { to career 1) }\end{array}$ & 2 \\
\hline Israel & 10 & Gender & 4 \\
\hline Biblical archaeology & 2 & Israel's Exodus & 1 \\
\hline $\begin{array}{l}\text { Southern Levant (4h) (presentations on Israel, except one on } \\
\text { Jordan) }\end{array}$ & 1 & Southern Levant (with 2 presentations on Israel) & 1 \\
\hline Southern Phoenicia & 2 & Northern Levant/Levant interconnections & 2 \\
\hline Jordan (Madaba project) & 2 & $\begin{array}{l}\text { Honor Thomas Parker (mostly Jordan); Jericho-Tel Hammam } \\
\text { (MB and LB) }\end{array}$ & 2 \\
\hline Mesopotamia & 1 & Mesopotamia & 2 \\
\hline \multirow[t]{2}{*}{ Iraqi Kurdistan } & 2 & Egypt (1), Egypt-Levant (Hyksos, 2) & 3 \\
\hline & & Arabia (3), Libya (1), Turkey (5), & 9 \\
\hline
\end{tabular}

Table 7: Geographical Areas - ASOR and Member Sessions.

\begin{tabular}{|c|c|c|c|c|c|c|c|c|c|c|}
\hline Area & & Aegean & & Arabia & Asia & Cyprus & Egypt & General & Iran & Iraqi Kurdistan \\
\hline ASOR & & 4 & & 19 & 5 & 24 & 11 & 17 & 9 & 18 \\
\hline Member & & 5 & & & 7 & 1 & 24 & 52 & 6 & \\
\hline Area & Israel & & Jordan & Lebanon & Levant & Libya & Mesop. & S. Phoen. & Syria & Turkey \\
\hline ASOR & 74 & & 23 & 14 & 12 & & 14 & & 9 & 17 \\
\hline Member & 94 & & 31 & 3 & 10 & 5 & 40 & 8 & 13 & 23 \\
\hline
\end{tabular}

Notes: Mesop. = Mesopotamia; S. Phoen. = South Phoenicia; add three M-presentations on Palestine and one A-presentation on Tunisia. Total 601 presentations (excluding the plenary presentation). 


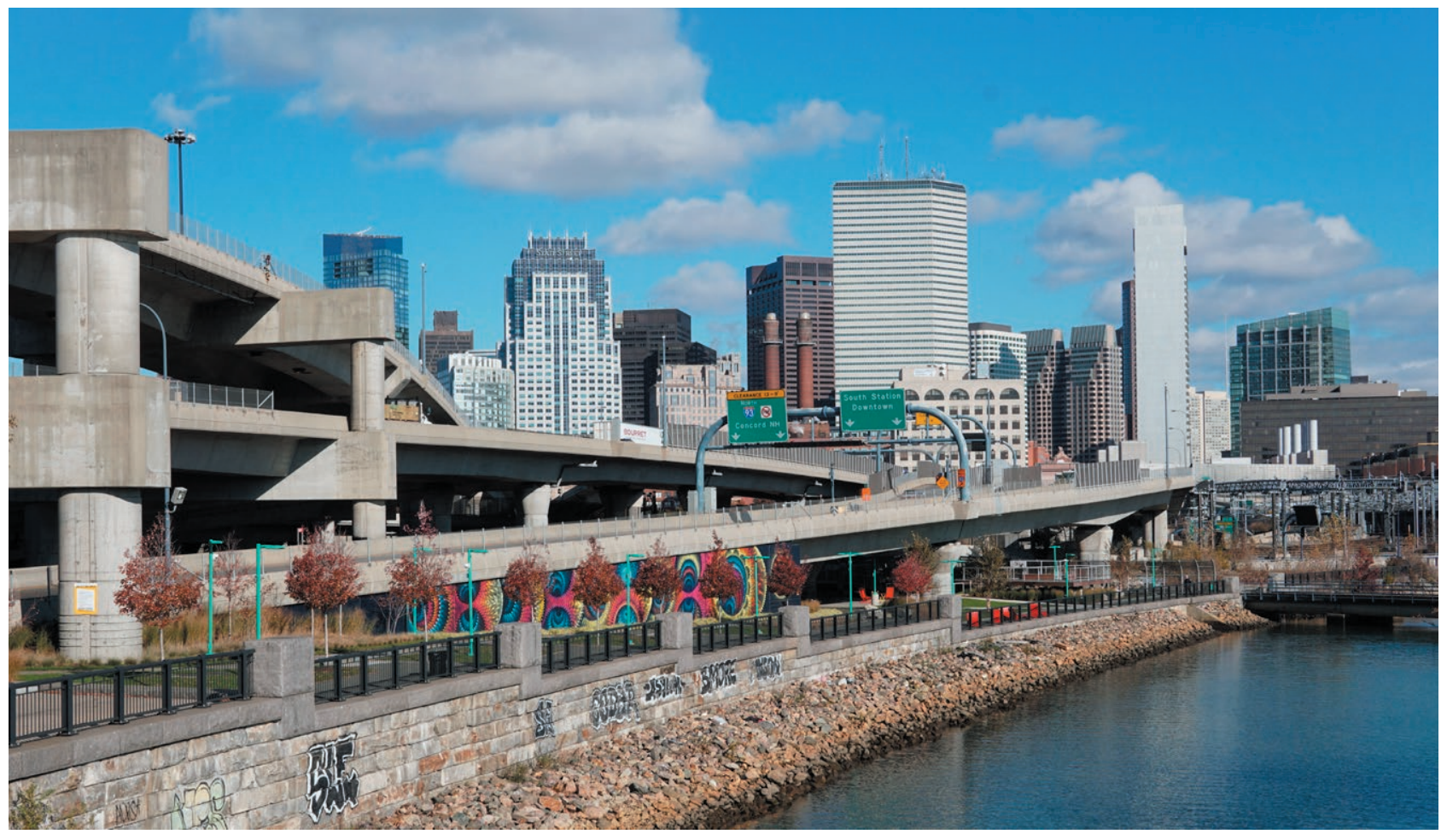

Fig. 1: Boston, November 2017 (R. Kletter). 


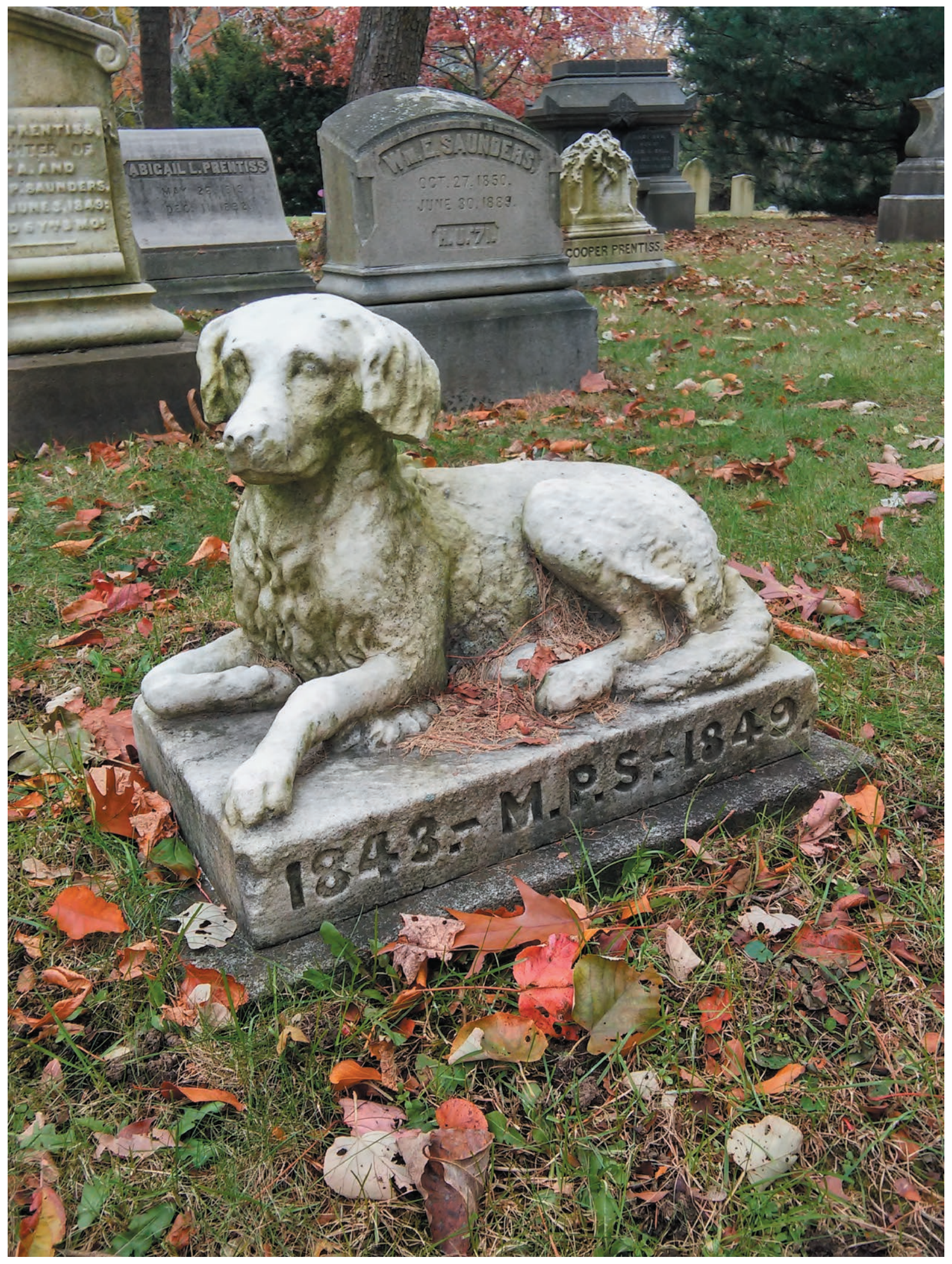

Fig. 2: Boston, November 2017 (R. Kletter). 